\title{
完成霜再植後の治癒過程に関する実験的研究
}

\author{
九州霜科大学口腔外科学第 1 講座（指導 : 山田長敬教授） \\ 村田始
}

炤和 60 年 2 月 $21 \mathrm{H}$ 受付

\section{An Experimental Study of Healing Process of Replanted Mature Permanent Teeth}

\author{
Hajime Murata \\ First Department of Oral Surgery (Director: Prof. Nagayoshi Yamada) \\ Kyushu Dental College, Kitakyusyu, Japan.
}

A replantation experiment was conducted with use of 52 teeth with the completed root formation (upper and lower central and lateral incisors: $\frac{1}{1} \mid \frac{2}{2}$ ) of 14 matured Japanese monkeys, Macaca fuscata (1 in control group and 13 in experimental group) and pathohistologic investigation were made.

The results were as follows:

1. At the tears observed in the periodontal fibers and around the tears, fibroblasts actively proliferated from 3 rd to 5 th days after replantation. On 10 th day, new minute collagen fibers were observed. From 15th to 20 th days, tears became unclear and presented conditions like those of normal periodontal tissue, from 30th to 45th days.

2. From 3rd to 10th days after replantation, a decreasing tendency of fibroblasts and degenerative changes such as hyaline degeneration were seen in part of the periodontal fibers. However, hyalinization of the fibers gradually decreased thereafter.

3. Partial resorption of the root surface was seen in all the speciment on and after 5 th days after replantation. The extent of resorption varied from as shallow as to cementum to as deep as to dentin.

4. Resorption cavities on the root surface were repaired by deposition of secondary cementum in all cases beginning on 15 th day after replantation.

5. Resorption of the alveolar bone began on 3rd day after replantation and was marked from 5 th to 10 th days. From 15 th to 20 th days, osteoblasts appeared in the resorpted region and formation for restoration was seen.

6. Ankylosis between tooth and alveolar bone was observed in only one each on 15th, 45 th, and 75 th days after replantation.

7. Healing on the basis of restoration to normalcy of the periodontal membrane was seen in 49 of the 52 cases. 
Based on the foregoing, replantation appears to be an effective method and healing by normal periodontal membrane can be expected provided the following conditions are met:preservation of the periodontal membrane, freshness, replantation of the tooth within 15 minutes after extraction and proper treatment of the pulp.

\section{Key words : Replantation/Healing process/Japanese monkey/Incisor}

\section{緒 言}

载牙再植とは，脱落または抜去した菌牙を再びもとの 歯槽に植立し，歯と歯槽骨との線維性結合の回復を計る ことである゙'。

再植の試みは古くより行なわれており最初に報告した のは, Ambroise Paré (1575)22 であると言われてい る. その後, 臨床的, 実験的に多数の報告があり, 再

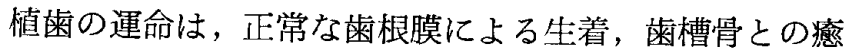
着および吸収による脱落のいずれかであると言われてい る。

再植を成功させるためには，つまり正常な歯根膜での 生着による回復は, 歯根膜の残存, 再植雪の口腔外放置 時間などによる歯根膜への影響や根完成歯では歯髄処置 などが関与すると言われている。

菌根膜の残存について臨床的には，森 $(1928)^{32}$, Talin 弓 $(1966)^{4)}$, Bielas ら $(1959)^{51}$, 実験的には Hammer $(1934)^{6)}$, Löe ら $(1961)^{7}$ の報告があり, いずれも柬根膜の必要を述べている.

さらに歯根膜の生存性, 歯根の吸収, 歯根と歯槽能の 強直 (瘾着) に関しては再植雨の口腔外放置時間に大き く影響を受けることが，Löe ら (1961) 7)，Flanagan 弓 $(1958)^{81}$, Andreasen $ら(1966)^{91}$, Edwards (19 66) ${ }^{101}$, Söder 弓 (1977) 11), Reichldt 弓 (1977) 12) により研究され，再植までの時間は短いほど良いと報告 している.つまり, 雪の再植には䨑根膜の存否と鮮度に 重要な鍵があるようである。もう一つの大きな要因とし て根完成崡では，歯髄処置が問題になり， Andreasen ら (1966 $)^{91}$, Edwards $(1966)^{10)}$, Knight ら (1964) 13), Barbakow 万 (1977) 14), Michel 万 (1982) 15) により根充処置した方が良好な結果が得られると述べら れている.さらに歯根膜の障害が著しくない場合には， 線維性組織で完全に治癒し霜の正常な支持が回復する ことが, Hammer $(1934)^{6}$, Michel ら $(1982)^{15)}$, Andreasen $(1972)^{16)}$, Nasjleti 弓 $(1975)^{17)}$ の病理 組織学的研究で報告されている。

しかしてれらの実験結果は, 実験動物の種類, 年令,
実験方法，観察方法および観察期間などが異なるため一 致した見解が得られていないむむしろ再植歯の運命を左 有する䨑根膜線維の新生機転に関しての定説はなく，不 明の点や種々の問題を多く残しているようである.

そこで著者は，七トに最も類似したニホンザルの完成 歯を用いて再植の奏験を行ない若干の知見を得たので報 告する.

\section{実験動物ならびに実験方法}

\section{I ．実験動物}

実験には，ニホンザル（Macaca fuscata）14頭を使 用し，そのうち対照群 1 頭，実験群 13 頭とした。年令 は, 桐野ら (1964) ${ }^{18}$ のニホンザルの蒾牙年令に準し， 第 3 大曰歯が十分に萌出した完全な永久歯列弓を有する 8 歳の成猿を使用した。実験動物は 1 週間観察飼育し, 健康を確認した後実験に供した。

\section{II . 実験方法}

実験は該動物を塩酸ヶタミン注射液 $7.5 \mathrm{mg} / \mathrm{kg}$ 亿て全 身麻䣲し, 通法のごとく手術器具ならびに手術野の消毒 を行なった。ついで $2 \%$ ピレナミン添加塩酸りドカイ

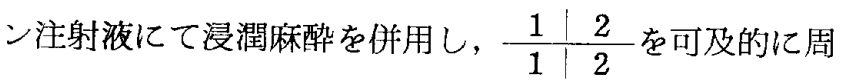
囲組織，特に曾根膜組織を損傷しないようにして通法に 従って拔菌した，根完成蒾であるてとを確俧した後, 抜 去雨牙の雪根膜を出来るだけ損傷しないようにし，通法 により拔鹃道己根充を施し再植した.以上の操作中は, 抗生

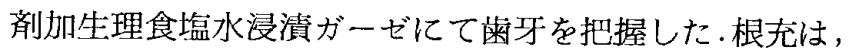
ガッタ・パーチャーと亜鉛華ユージノールセメント（キ ヤナルス)を用い, 再植米の固定は隣在歯を利用し 0.3 $\mathrm{mm}$ の18-8 ステンレス線にて二歯結禁した．その上， 固定を確実にして再植菌の脱落を防止するためレジンに て隣在歯と再植歯の唇面を被覆した，再植歯への刺激を 避けるため, 切端を削除した。技菌から再植固定までの すべての操作は15分以内で完了した．術後感染-予防のた め, ペニシリンGゾル30万単位を術後 7 日まで連日筋肉 内投与した。

III. 観察方法 
実験後，3，5，10，15，20，30，45，75，90，120， 150，180，210日目にてそれぞれをぺントバルビタール ナトリウムにて薬殺し, 断頭後, $10 \%$ ホルマリン液にて 固定した。固定後，再植雪部を採取し，5\%硝酸液にて 脱灰した後，通法に雃ってセロイシン包埋し約 $15 \mu \mathrm{m}$ 亿 て唇舌 (口蓋) 的な連続切片䅺本を作製, ついでへマト キシリン・エオシン重染色，アザン・マロリ一染色を行 ない鏡見した。

所

見

正常所見

上額中切来ならびに側切歯

ヒトと同様に唇側䨑槽骨は口蓋側に比して薄く，歯槽 縁の高さは唇側の方が口蓋側よりも下方に位䈯してい る・歯槽骨の内壁はヒトと同しく線維骨と層板骨よりな っている。

歯槽骨の内壁面は，1〜2層の線維骨で被覆されてお り，その表面には骨新生が著明に認められる(写真 1 ).

唇側歯槽縁から雪根膜側に面する歯槽内壁面と歯槽外 壁面には，単層の骨牙細胞の配列が䛱められ骨新生が観 察される. 根尖側 $1 / 3$ 亿対する米槽骨内壁面には部分的に 浅い吸收曧が見られる。

口蓋側の菡槽縁から根尖までに至る歯槽内壁面には常 芽細胞が多数認められ，骨新生像が伺われる（写真 2 ).

セメント質表面にはセメント芽細胞が規則正しく配列 している(写真 3 ).

唇側㐘根膜においては画槽頂線維束の発達が著明で， 全体的に斜走線維の発達が良く線維芽細胞に富んでい る、水平線維の発達はほとんど見られず，わずかに歯槽 縁下に認められるのみである。

口蓋側は歯槽頂から根中央部にかけて水平線維が発 達し，根尖側 $1 / 3$ の部において 斜走線維の発達が見られ 万.

根尖部では，よく発達した根尖部線維が放射状に走っ ている(写真 4 ).

蒾根膜線維はセメント質と歯槽内壁面では，それぞれ 太い束をなしているが，セメント質側では歯槽内壁側よ りやや細い，困根膜腔の中間の線維束は紐くなり，互い に双方から線維束と連続している.

霜根象牙質表面には薄い無細胞セメント質が認めら れ，根尖側 $1 / 3$ の根部には，さらに第 2 セメント質の添加 があり肥厚している。蓋側における第 2 セメント質の 添加はさらに厚い。

下顎中切歯ならびに側切歯
ヒトと同様，歯槽緣の高さは，唇・舌側ともほぼ同じ で薄い，唇側の歯槽骨は菌槽頂から雪槽縁にかけて骨の 吸収窩がわずかに認められる，曾槽骨の外壁面には骨芶 細胞が多数存在し，萑干の骨新生が見られる。舌側歯槽 内壁においては，歯槽頂から歯槽緣部にかけて䒿の新生 が見られる。

舌側雬槽外壁には軽度の败収窩が認められ，ところど ころ，深部骨䯑進腔面にも败収窝が認められる。また舌側 根尖側 $1 / 3$ に相当する雪槽内壁にも吸収浻が観察される.

セメント質表面にはセメント芽細胞が諗められる.

唇側爾槽縁部に打ける水平線維の発達が良好で，細い 線維群は弛緩し，ゆるやかな波状を星している。歯根中 央部より根尖側 $1 / 3$ に相当する部における, 斜走線維の発 達も著明である。

歯根象牙質表面は薄い無細胞セメント質に被われ，吸 収所見は見られない。

以上，上・下顎切歯所見は，ヒトのものと類似してい る。

再植夹験 3 日目所見

\section{a . 歯根膜}

歯根膜組織には，全体的に炎症細胞の浸潤が認めら れ, さらに罱随内においても炎症細胞の浸潤が認められ る.

柬根膜線維には，歯根膜腔の全周にわたり不規則な 断裂像が明膫で，その部は挫滅と出血愁として認められ る。断裂した菌根膜線維には，線維来細胞をはじめ筲芽 細胞，セメント芽細胞の減少之消失傾向が認められる. また部分的には硝子変性も観察される。乙れは口蓋側に おいて著明である。断裂部周囲には，逆に線維牙細胞の 堌殖が見られる 蚂真 $5 \sim 7$ ）。

b. 歯槽你

圈板骨のハバース管は抬大傾向を示す．また，八バ 一ス管内は骨の新生した部や血管の搪掁と充血が認めら れる、歯槽骨の吸収は，口蓋菌槽学外壁に見られるのみ である・

c . 蒾根

畨根の吸収は，どこにも認められない。

再植実験 5 日目所胃

a . 蒾根膜

棶根膜組織には，前期例と同しく全体的に炎祉細胞の 浸潤が認められる。

歯根膜線維の断裂部は 3 日目よりやや不明瞭になる. 
この部の出血樂は，全体的に減少傾向にある。

断裂した茵根膜線維には，唇・蓋側とも全周におい て骨芽細胞，セメント芽細胞の減少と消失傾向が見ら れ，また線維牙細胞の減少と融解む認められる。なお， 3 日目まで部分的に観察された硝子変性の領域は減少傾 向にある。

残存歯根膜線維は，全周において数も少なく疎性化 し，歯根膜線維の走行はほとんど見られない。

断裂部周囲には，逆に線維讶細胞の增殖が旺盛であ る。

b . 菌槽县

唇側蒾槽骨の歯槽頂から根中央部にいたる柬槽内壁に は，連続した吸収窝が認められる(写真 8 )。

口蓋骨，骨髄内および根尖部に相対する雪槽骨部に は，破骨細胞を伴ったハウシップ小窝が多く認められる (写真 $9 ， 10)$.

\section{c . 歯根}

唇側歯頸部に近い部のセメント質表層に吸収窩が単独 あるいは数個見られる。しかし，その吸収は浅く，象牙 質におよんでも極く表層に限定される。

再植実験10日目所㫕

\section{a . 匈根膜}

歯根膜線維の断裂部は，5日目に比べ全体的にさらに 不明暸となっている、断裂部およびその周囲には線維牙 細胞の増殖が認められる (写真11). 口蓋側根中央部に 相当する部においては，極く一部ではあるが，細い翏原 線維の新生が認められる (写真12).

断裂した㧘根膜線維には線維芽細胞の娍少と消失傾向 が見られ，骨牙細胞やセメント芽細胞は見られない。部 分的に硝子変性も見られるが，5日目に比して減少傾向 にある.いまだ雨根膜線維の連続は不十分である。

\section{b . 歯槽,骨}

唇・蓋側蒾槽骨とも内外壁の表層はエオシンに淡染 した骨新生が認められる，骨㵦内の吸収窝も骨新生によ って修復されている。

しかし，一部には破骨細胞も珰められる（写真13）.

c. 歯根

菌根の吸収は，5日目とほとんど変化は見られない。

再植実験15日目所見

a . 菌根膜

菌根膜線維には, 全体的に軽度な炎症細胞の浸潤が認 められる。
㐘根膜線維の断裂部は10日目より不明瞭になり，断裂 部での雪根膜の連続は見られない。

歯根膜線維には, 線維芽細胞の増殖が見られ, 粜根膜 線維の連続性も見られるようになるが，不規則な配列の 部も認められる。10日目までに観察された硝子変性は， この段階にてほとんど認められない。

セメント牙細胞は, 口蓋側根中央相当部に一部観察さ れるのみで, 全体的にはほとんど見られないと言ってよ i.

口蓋側蒾槽縁より柬槽骨内壁に面して骨牙細胞が部分 的に認められる (写真14〜16).

\section{b . 梀槽骨}

10日目に比べて霜槽骨の吸収は軽度である，口蓋側歯 槽縁外壁には，破骨細胞を伴った吸収曧が認められる が，それ以外の部には骨牙細胞の増殖と骨新生の所見が 見られる、唇側・口蓋側とも歯槽縁部の歯槽骨内壁には エオジン淡染した新生骨が浔められる.

\section{c . 画根}

歯根の吸収は，10日目より吸収窩が随所に認められ る。唇側根尖側 $1 / 3$ の部には，また歯根と歯槽骨の強直が 一部認められるところもある（写真17）.

\section{再植実験20日目所見}

\section{a . 菌根膜}

菌根膜線維の断裂部は 15 日目よりさらに不明瞭であ る. しかし全体的に雬根膜腔の線維の数は増し, 小血管 も認められるようになり，とくに唇側と根尖部において 多く見られる (写真18〜20).

雨根膜線維の走行は，さらに規則正しくなる部が随所 に見られる。乙の部の線維はセメント質および歯槽骨へ の進入状態も良好である.しかし, 唇側根尖側 $1 / 3$ の部に は，線維の疎性化が見られ，歯槽内壁の吸収部には線維 の見られないところもみられる (写真21).

セメント質表面には，規則正しく配列したセメント芽 細胞が見られる.一部の根尖部周辺にはセメント牙細胞 は認められない。

\section{b . 歯槽骨}

唇側㐘槽骨の内外壁表面には，骨芽細胞を伴った骨新 生が旺盛である(马真22)，特に歯槽縁部の骨新生が著 明である。口蓋根尖側 $1 / 3$ 亿相当する歯槽内壁も骨新生が 著明である。

骨髄内壁の骨新生も著明で，骨昅収像は見られない (写真23).

c. 歯根 
米根の级収部は全体的に第 2 セメント質により修復さ れた像がみられる。

\section{再植実験 30 日目所見}

\section{a . 蒾根膜}

歯根膜線維の断裂部は認められず，唇・口蓋側菡根膜 線維の配列と走行は規則正しくなり，その連続性も良く 保ち，セメント質抢よび㐘槽骨への進入も良好である。 セメント質表面にはセメント牙細胞の配列が認められる (写真24, 25).

b . 㐘槽骨

唇側䨑槽骨の内壁に面する部には，エオジンに淡染し た新生骨が認められる、口蓋骨骨髄腔面には学吸収が認 められ，口蓋歯槽骨内壁の冝吸收部には新生骨が芫られ る・破骨細胞は認められない。

c . 菌根

唇側宷頸側 $1 / 3$ の蒾根吸収部は，第 2 セメント質の添加 により修復されている(写真26).

\section{再植実験 45 日目所見}

\section{a . 雬根膜}

蔯根膜腔は，30日目に比へて全体的に雬根膜線維の走 行, 連続性ともに良好である. 唇側歯根膜の歯槽頂なら びに歯槽縁には弛緩した細い線維が配列しているが，や や不規則である．舌側雬根膜の歯槽頂には，発育良好な 斜走線維が見られる、根尖部には，やや不規則ながら発 達した線維が多い（写真27）。セメント質表面には全面 にわたってセメント芽細胞が見られる。

\section{b . 歯槽霄}

下頭唇側㐘槽骨内壁は柱状にのびた新生骨が認められ

る、骨髄腔面も骨芽細胞を伴う骨新生が旺盛である。

c. 歯根

前期例所見とほとんど変らない。

\section{再植実験75日目所見}

a . 峲根膜

45日日所見と著変は見られない。

歯根膜線維の連続性は, 唇・口蓋側歯根膜腔ともさら に強固となり，走行，配列も正常に近い機能的配列を示 す.

歯根膜線維のセメント質, 歯槽骨への進入も良好であ る (写真 28,29 ).

畨根膜線維は口蓋側の方がやや粗である（写真30）。 根尖部線維の走行も規則正しく放射状に配列し，良好な
発育を示している。

セメント質表面には，セメント芽細胞がほぼ規則的に 配列している.

\section{b . 歯槽骨}

唇側䨑槽骨の内外壁とも骨新生が著明である，骨髄内 の一部に，破骨細胞を伴う骨吸収が見られるところがあ る。

c. 歯根

菌根全面にわたって進行性の吸収は認められず，唇側 の根尖側 $1 / 3$ の部の象牙質におよふ吸収部は第 2 セメント 質で修復されている。

\section{再植実験90日目所見}

\section{a . 歯根膜}

75日目所見とほとんど変化は見られない，

歯根膜線維の発達は全体的に良好で, 走行, 配列とも に正常に近い(写真 $31 ， 32$ ).

菌根膜線維のセメント質，歯槽骨への進入も正常とほ とんど変らない。

\section{b . 歯槽骨}

唇・口蓋側とも，歯槽骨内外壁に新生骨が認められ る.

\section{c . 歯根}

75 日目例と著変はない。

再植実験 $120 ， 150 ， 180 ， 210$ 日目所見

前述所見之著変は見られない，雨根膜，㐘槽骨および 歯根所見之も全く正常所見を呈す（写真33〜36）.

\section{考察ならびに総括}

雪牙再植に関する臨床的，実験的研究は比較的多数見 られる。

再植術を成功に導くため，つまり正常な歯根膜を回復 するためには，歯根膜を損傷させず，残存する歯根膜の 生存が最も重要であると言われている3へ12)。また，根 完成歯の再植においては, 柬葡処置が重要であるととが 報告されている9,10,13-15)。

しかし，再植歯の運命として問題となっている㐘根の

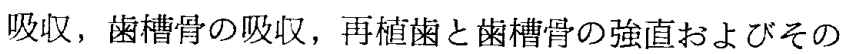
治療機転などについての定説はなく，不明の点や種々の 問題を残しているようである.

そこで著者は，ヒトに最も類似しているニホンザルを 用いて再植実験を試み，病理組織学的に検索して前述の ような所見が得られた。これらの所見について文献と対 
比しながら考察する。

再植蒾の治痖過程について

酒井 (1919） ${ }^{19)}$ によろイヌの完成歯の再植実験によ れば，1）断裂した䨑根膜の第一期癒合をするもの， 2）歯根面の吸収窩に肉芽組織が進入して結合するも の，3）骨性療着をするもの，の 3 型を挙げている. そして，てれらは混在して見られると記載している.

Andreasen (1971) ${ }^{201}$ は，1）正常な㐘根膜による生 着，2）歯槽骨との骨性瘾着（置換吸収），3）吸収に よる脱落（炎症性吸収），を述へ，いずれも1）の治療 が良いとしている。

再植菌の治療は咬合機能上から 1）の過程が望まれる が，てれに関しては種々の具体的な研究がある.

臨床的に森 (1928) ${ }^{32}$ は，歯根膜を保存したもの之除 去したものを比較して, 前者の方が良い結果を得たと報 告している. Talin ら $(1966)^{4)}$, Bielas ら (1959) ${ }^{5}$ も歯根膜の必要性を述べている。一方，実験的にも， Hammer $(1934)^{61}$, Löe ら $(1961)^{7}$ の報告が見られ るが，同じく歯根膜の保存が良結果の条件として挙げて いる。

本実験の結果では，52例中 49 例の正常回復を見ている ので, やはり歯根膜を保存することが必要条件であろう と考える。

再植するまでの口腔外放置時間については, Flanagan ら $(1958)^{81}$ はシリアン八ムスターを用いて実験を試み ている. 30 分， 6 時間， 24 時間， 48 時間放置した後の再 植実験では，30分以内のものが最も予後良好であったと 記述している. Löe ら (1961)" はイヌとサルで15分, 20 分， 45 分， 120 分之経時的に曾槽外時間を変えた実験 を行なっている，その結果，15分が最も経過が良好で あったと言う. Andreasen ら (1966) ${ }^{91}$ あ30分以内に 再植されたものが結果が良いと報告している．また，

Edwards (1966) ${ }^{10 !}$ もイ邓における実験で15分以内に 再植したものが79\%に回復が証明されたが，歯根膜が破 壊されたグループは $21 \%$ 回復のみであったと報告して いる。てのように口腔外放置時間は，30分以内が良いと いうデーターが多い。

口腔外放置時間による㐘根膜細胞への影響について, Söder ら (1977) ${ }^{11)}$ は, 動物実験にて菌根膜の生存細 胞の数は, 乾燥時間の増大とともに急速に落ち込み, 120分を越えると不可逆性の細胞の障害があると報告し ている。

歯根膜の細胞の培養実験について

Reichldt 弓 $(1977)^{12}$ は，サルの切䨑を使用しての
培養実験で40分以内の乾燥時間であれば生存した細胞が 見られると報告している。

再植歯の歯槽外時間は，歯根の吸収にも大きな影響が あると言われている. Andreasen (1971) 20 ) は再植歯 の根吸収の原因として口腔外時間が密接に関与している と述べ, Löe ら (1961) ${ }^{71}$, Kaqueller $(1969)^{211}$, Ravn 弓 $(1966)^{22)}$, Cvek 弓 $(1974)^{23)}$, Lenstrup ら (1959) 24) らは, 臨床的に進行性の骨吸収を記載して いる. Reichldt ら $(1977)^{12}{ }^{2}$ は，40分以内に再植すれ ば根の吸収は予防できると報告している。乙れらの報告 のように，再植を成功させる要因として歯根膜の保有 性, 歯根膜細胞の生存が重要であり, 再植されるまでの 時間が短い方が良いというのが通説である。

さらに，再植を行なう場合の今一つの大きな要因と

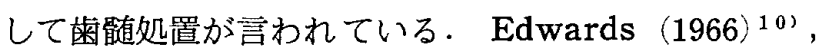
Knight ら (1964) ${ }^{13)}$ らは，根管充填をした方が，し ないよりを成功していると述べている，Andreasen ら (1966) $\left.{ }^{9}\right)$ は，歯唱組織の壊死によって産生される毒素 が，歯根の炎症性吸収を起てすであろうことを示唆して いる.このためには，根完成菌では粜髄処置が重要なも のであると述べている. Barbakow ら (1977) ${ }^{14)}$ は32 頭のサルを用いた実験で，根允したものと，しなかった ものの䨑根膜の治瘾過程を $1,2,4,8$ 週間観察し て，上皮の付着，根の吸収，骨性癒着などには差は見ら れなかった。 そして，根允しなかったグループでは根尖

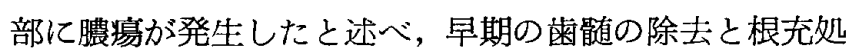
置が必要であると結論している. Michel ら (1982) ${ }^{15)}$ も，イヌの実験で歯葡処置をした方が良結果を得た之述 べている．てのように根完成霜においては，臨床的にも 実験的にも歯髄処置が必要であろうというととは多くの 研究者の一致した意見のようである.

著者の実験では，以上のようなととを考慮しながら抜 霜から根管処置，再植までの操作を15分以内で完了する ようにした。本実験に扔いては，抜歯後菌根部を抗生剂 加生食水に浸したガーゼにて歯根膜を可及的損傷させな いように被覆して，拔菌，根允を行った。根充㓮として は, 日常臨床で用いられているガッタ・パーチャーポイ ントと亜鉛華ュージノールを用いた，以上の上う亿先人 の㬰験結果を参考にして処置を行なえば，もっとも良い 結果を得るてとが出来るととを確認した.

このことは，雨根膜の保存，再植歯の口腔外放置時 間，歯䯣処置などを考慮しながら可及的短時間のうちに 再植術を行なえば行なうほど脱落歯を保存するととは可 能であると考える。 
再植歯の根吸収, 䨑根と蒾槽骨の強直あるいは周囲組 繊の影響についてみると, Andreasen (1971) ${ }^{201}$ は良 好な治㿑過程を経たものでも歯根表面の小範囲に表在性 の吸収窩が見られ，後でセメント質の添加により修復さ れると述べている，酒井 $(1919)^{19)}$ は，歯根の吸収は 3 日目上り起てると述べ，吸収が著明に現われるとてろ は, 根端 $1 / 3$ 部と霖頸部に近い部に多いと記載している。 またてれら歯根の吸収の起こる部位としては，特に根尖 1/3部之雬頸部に近い部に起こり易いと述べ，また歯槽 に加わる不均等力により吸収が起こると述べている。こ の点に関する著者の実験においてもほとんど同様な所見 を呈していたといえる. Michel ら (1982) 151は，サル の蒾牙について 3 分以内の再植実験を試み，21日目で雨 根表面の一部に第 2 セメント質の添加が見られ，その他 大部分の菊根面には修復も活動性の吸収も見られなかっ たと報告している．Edwards (1966) ${ }^{10)}$ は，根表面の 吸汉窩は広範囲の吸収でもセメント質の添加で修復され ると述べている。また， Nasjleti ら $(1975)^{17}$ はサル の㐘にて歯髄処置をした再植霜の固定期間の違いが，根 吸収之骨性癒着の発生に相異が見られ，7日閒の固定で は，すみやかに柬根膜の回復が認められるが，30日目の 例では崡根の吸収と歯根と歯槽骨との強直が促進された と言う。また，Andreasen (1975) 25) も短時間の固定 を推奖している. Barbakow (1977) ${ }^{14}$ は，歯䯣処置雪 之無処置蒾の再植実験において, 両群とも2 週間で強直 のきざしが見られ，無処置群では，七メント質に浅い吸 収窝を 4 週目では象牙質まで進行した吸収窝が見られる と述へ，両群とも同様な結果であり，さらに 8 週間で両 群とすすべての例に強直を認めたと述べている。

著者の 5 日目実験例の標本では，歯根尖 $1 / 3$ の部におけ る吸収が多く，ついで歯根中央部よりやや上方に多かっ た．吸収は極めて小部分に限局して起こる場合や，広範 囲にわたって起こることもあった，吸収の程度もセメン 卜質のみの浅いものから象牙質におよぶものまでさまざ まであった。なお，歯根表面の吸収窩の第 2 七メント質 による修復は，15日から20日以後のもので観察された。 この歯根部の吸収は酒井 $(1919)^{19}$ の実験成績よりやや 遅く起こり, Michel ら (1982 ${ }^{15}$ ) の吸收部における第 2 セメント質の添加より著者の実験の方が早く起こって いる。乙机は，再植蒾の抜蒾創への適合と固定による再 植煉の変位がなかったとと，固定期間を短くすることな ぞにより好結果を得たのであろうと思われる。

本実験に打ける蒾根と蒌槽骨の強直をみるに，再植後 15日所見ではじめて，一部強直が認められた。前述した
Barbakow（1977）14（の所見と比較するには多少の難は あるが，ほぼ同時期に強直が見られたといえる。

以上の様に再植歯における歯根の吸收，強直について の所見は一定していないようである。一般的に菌根が汲 収される場合は外傷によるセメント質の吸収, 矯正力に よるセメント質の吸収，再植歯や移植歯の雬根の吸収な

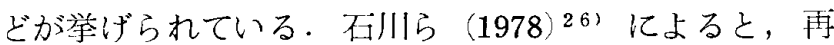
植爾ではほとんど完全に歯根膜の形成をなして正常に近 い線維性結合を形づくるが，時として何らかの原因で破 歯細胞によるセメント質の吸収を起こすととがある。さ らに，その後著しい骴新生をきたし二次的に歯槽骨と少 性癒着，すなわち強直を起こすと述べている，何らかの 原因については，いまだ不明な点が多い，歯根と㐘槽骨 の強直について，艾合機能を営んでいる歯ではセメント 質の吸収や新生は歯槽骨よりも起こりにくい，また，根 が歯根膜線維で可動性に歯槽内に結合されているのでセ メント質や骨で癒着をきたすととは通常の場合はない。 しかし例外的に機能歯でも歯根膜に強い塤死が広範囲に 起こると二次的に強直をきたすととがある.つまり圧迫 された歯根膜が広範な壊死を起こし，圧迫側の歯槽骨が 吸収される時にセメント質も吸収を受けその後, 新生さ れた骨組織によって強㨁を起ししたとみなしている。戸 村ら $\left(1957{ }^{27}\right.$ は壊死倠った歯根膜は，しばしば石灰 沈着をきたしセメント質と雪槽壁を結合させ，ついで障 害をま奴れた隣接骨娟道から肉芽組織が増殖し，同時に 壊死部の歯槽壁，セメント質および石灰化菌根膜などに 收造吸収が起こり，ついで骨の新生が起こって蒾根之蒾 槽骨の強直が完成すると述べている，石川ら $(1978)^{261}$ は，再植歯や移植歯の強直の場合も時によっては歯根 セメント質に吸収が起てらないで歯槽骨の増殖によって セメント質と骨性傯着を来たすことがあると述べてい る。

著者の実験における強直は15日目ではじめて認められ た。強直は，小箸囲に起こる場合や広範囲に起こる場合 もあった．本実験群52本中 3 本に強直が見られた。この 強直の起きた原因ならびに経過については，発現例が少 ないため，前に述べた種々の原因により起こったのであ ろうと考える。この上うな所見について石田 $(1972)^{28)}$ は，歯と骨の違い，生体反応市るいは破悼細胞抢よび造 管細胞の機能に対する考え方など，何か別の問題がある ように思われ，今後さらに追求すべき重要課題であろう と述べている.

再植後周用組織の病理組織学的な治癒過程についての 実験的研究は, Hammer (1934) ${ }^{6}$, Michel ら (1982) 
15), Andreasen (1972) 16), Nasjleti ${ }^{16}(1975)^{171}$ の 報告が見られる.1934年 Hammerは, 幼若イヌを用い た実験で，歯根膜部の組織学的変化は，再植後間もな く，歯根側と茵槽骨側との間隙が埋められ，2 週間後に 膠原線維力゙新生し 4 週間後に治療が完了すると述べてい る. Andreasen (1972)16) は正常治癒したものは，2 〜 3 力月後には正常な歯根膜組織内に発達した幼若な膠 原線維が新生されるとしている. Nasjleti ら(1975)17) はサルを用いて再植雪の治瘺過程をラジオオートグラフ にて観察し，結合組織の増殖は，主に骨頂部および骨髄 腔部から始まり，その活甠は 7 日でピークに達し, 若い 結合組織で雨根膜は接着するが線維の配列と成熟は 4 力 月後に認めている.蒾肉上皮は再植後直ちに増殖をはじ め，その活性は 3 日目でピークに達し，7日目後に新し い上皮による再付着が確立する。また，セメント牙細胞 の出現は 4 週間まで見られないと述べている。また良好 な治癒が終るまでセメント芽細胞は出現しないと述べ, セメント牙細胞は二次的に線維の付着の役割をしている ことを示唆している.

本夹験において，3日目ではまだ断裂部は明瞭であっ た. 再植後 5 日目では, 断裂した歯根膜線維の細胞の诚 少が見られた。また，残存した線維の数も少なく疎性 化していた。断裂した両曾根膜はともに硝子化が認め られ，全体的に連続は見られなかった。再植後10日目で は，断裂した両荬根膜には線維芽細胞の増加之一部細い 䢧原線維の新生が見られ，断裂部は次第に不明瞭化し， 線維の走行もいまだ不規則であるが線維の発育も良好な 部が見られるようになる. 20 日目では, 線維の機能的配 列が一部認められたが，早いものでは15日目でも認める ことが出来た．線維の走行も規則正しくなり30〜45日目 では，歯根膜線維は正常な配列と成熟が見られ，線維の 連続も良好となった。

再植後 3〜10日目では, 断裂した函根膜線維には線維 茅細胞の減少と硝子化などの退行性病変が起こっていた が，線維の硝子化を観察した報告は, Michel ら (1982) 15), Nasjleti ら (1975) 17)のものが見られるのみであ る

歯根膜線維の正常化については, Hammer (1934)6) は，4週間で治瘾が完了したと報告し，Nasjleti ら（19 75） ${ }^{17}$ は線維の配列之成熟は 4 力月後に認めている.ま た Michel ら (1982)15は，21日日ではまだ正常な線維 の形態はなしていないと述べている.

本実験においては，30〜45日目の例において，ほぼ線 維の正常配列と成熟が諗められ, 諸家の報告より線維の
硝子化は少し遅く，柬根膜の正常化は少し早期より始ま っていた・この点に関しては各動物の違い，夹験方法の 差異などで比較することはできないのではないかと考え る.

歯槽骨の変化について, 石川ら $(1978)^{26)}$ は, 矯正に よる宩の移動時に見られる菌周組織の変化の中で，圧迫 側で雪根膜の障害が軽い時（壊死，変性がない時）に蕋 槽壁面に破骨細胞が出現し骨が吸収される直接吸収と， 壊死を生じた部では, 直接吸収は起こらず隣接する生活 雨根膜の贵面あるいは壊死部の柬槽骨を吸収除去する下 掘れ财収とがあり，再植においても曾槽骨は，これら 両方の吸収変化があると述べている. Michel ら（1982） 15) は 3 日目に破骨細胞の出現, 骨髄腔の下掘れ吸収を 認め，7日目で骨髄腔の拡大と活動性の破骨細胞による 吸収を，21日目では7日目より変化が大であったと報告 している.

本実験では，3 日目の例で氣根膜に面する柬槽骨部で は, すでに吸収所見が諗め引れ，口蓋側の外層面では破 骨細胞を伴うハウシップ小窩が認められた５日目では 柬根に面する唇・口蓋蒾槽骨は破骨細胞を伴う吸収窩が 随所に観察され，骨骮腔内への影響も大で広範囲に破骨 細胞を伴った吸収窩が見られた．若干の経日的な差はあ るが，3〜10日目が䨑槽骨への影響が大であった。15〜 20日目では，雬槽骨周囲之骨髄腔内の骨芽細胞の増殖と 骨新生が盛んであった。

\section{結 論}

成熟したニホンザル14頭（対照群 1 頭，実験群13頭）

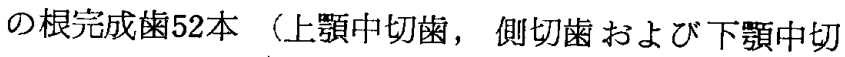
米, 侧切歯： $\left.\frac{1}{1} \mid \frac{2}{1}\right)$ を用いて再植実験を試み, 病理 組織的な検索を行なった・得られた主な知見は以下の通 りである。

1. 電根膜線維に見られる断裂部およびその周迅に は, 再植後 $3 \sim 5$ 日目にかけて線維芽細胞のさかんな増 殖が認められ，10日目では，細い膠原線維の新生が観察 された。15〜20日目にかけては，断裂部が不明瞭にな り，30〜45日目では，ほぼ正常な幽根膜組織の様相を呈 していた。

2. 断裂した菌根膜線維の一部には再植後 3〜10日目 にかけて線維芽細胞の減少傾向や硝子様変性などの退行 甠病変も認められた。しかし，乙の線維の硝子化はその 後漸減した。

3 . 柬根表面の部分的吸収は, 再植後 5 日目以後の標 本すべてに認められた。 その吸収程度は，セメント質 
のみの浅いものから象牙質にまで進行したものまであっ た。

4. 歯根表面の吸収窝は, 再植後15日目例よりすべて 第 2 セメント質により修復されていた。

5 . 歯槽骨の吸収は, 再植後 3 日目より見られ，5〜 10日目で顕著であった，再植後15〜20日目以後になる と，そこに骨芽細胞が出現し，修復のため骨形成が見ら れた。

6 . 歯根と歯槽骨の強直症例は，再植後 15 日目，45日 目，75日目の各例に 1本ずつしか認められなかった。

7 . 歯根膜の正常回復によって治瘾したと垫められる ものは52例中 49 例であった。

以上の結果より, 歯牙再植術は歯根膜の保存, 鮮度, 15分以内の口腔外放置時間および, 適切な菌葡処置が行
なわれれば，正常蒾根膜による治療が期待でき，有効な 方法であると考えられる.

謝辞

稿を終るに臨み，終始懇篤なる御指導と御校閲を賜り ました九州蒾科大学第 1 口腔外科学教室山田長敬教授, 第 2 口腔解剖学教室嶋村䀡辰教授に深甚の謝意を捧げま す.

また日夜をいとわず種々御教示，御指導を戴きました 野代忠宏博士に満腔の謝意を表わします。市わせて本研 究に種々御協力を戴きました鈴木俊介，樋田謙二郎両先 生はしめ第 1 口腔外科学の各先生に対し厚くお礼申し上 げます。

\section{参考献}

1) 石川悟朗・秋吉正豊: 口腔病理学 I. 永末書店, 東京, $1978,517-522$.

2 ) Ambroise Paré (1575)：園山 昇（菌牙の再植, 歯界展望33：635-638，1969）より引用.

3）森 忠男：䨑牙再植術の術式について。日本之歯界 $93: 12-20,1928$.

4) Talin, S.T. and Antia, F.E. : A roentgenographic evaluation of reimplanted teeth. O.S., O.M. and O.P. $21: 602-608,1966$.

5 ) Bielas, I. et al. (1959):28) ょり引用.

6) Hammer, H. (1934):16) より 引用.

7 Löe, H. and Wearhang, J. : Experimental replantation of teeth in dogs and monkeys. Arch. Oral Biol. 3 : 176-184, 1961.

8 Flanagan, V.D. and Myers, H.L. : Delayed reimplantation of second molar in the Syrian hamsters. O.S., O.M. and O.P. $11: 1179-1188,1958$.

9) Andreasen, J.O. and H. Hanssen, E. : Replantation of teeth, I. Radiographic and clinical study of 110 human teeth reimplanted after accidental loss. Acta Odont. Scand. 24 : 263-286, 1966.

10) Edwards, T.S.F. : Treatment of pulpal and periapical disease by replantation. Brit. Dent. J. 121: 159-166, 1966.

11) Söder, P. ̈̈., Otteskog, P., Andreasen, J.o. and Modeer, T. : Effect of drying on viability of periodontal membrane. Scand. J. Dent. Res. $85: 164-168,1977$.

12) Reichldt, J., Andreasen, J.O., Söder, P. 0̈. and Otteskog, P. (1977) : Cite by 11).

13) Knight, M.K., Benjamin, J.G. and Joseph, C.C. : The effect of root canal therapy on replanted teeth of dogs. O.S., O.M. and O.P. $18: 227-242,1964$.

14) Barbakow, F.H., Austin, J.C. and Cleaton-Jones, P.E. : Experimental replantation of rootcanal-filled and untreated teeth in the vervet monkey. J. Endod. 3:89-93, 1977.

15) Michel, P.P. and Alan, M.P. : Repair in different zones of the periodontium after teeth reimplantation. J. Periodont. $53: 379-389,1982$.

16) Andreasen, J.0. : Traumatic injuries to the teeth. Munksgaard, Copenhagen. 1972, 193-231.

17) Nasjleti, C.E., Raul, G.C., Walter, A.C. and James, A.H.: Healing after tooth reimplan- 
tation in monkeys. A radioautographic study. Oral Surg. 39:361-375, 1975.

18）桐野忠大・佐伯政友：高崎山野生ニホンザルの口腔内諸形態.〔高崎山の野生ニホンザル〕（伊谷純一郎・池 田次郎・田中利男編) 勁草書房, 東京, 1964, 124-135.

19）酒井櫠一：再植術について. 日本歯科医学会雑誌 $26: 29-68 ， 1919$.

20) Andreasen, J.0. : Treatment of fractured and avulsed teeth. J. Dent. Child. 38:29-48, 1971.

21) Kaqueller, J.C. and Masser M. Healing following tooth replantation. J. Dent. Child. $36: 303-314,1969$.

22) Ravn, J.J. en Helbo, M. : Replantation af akkidentelt esksartikulerede taenden. Tandlaegeblad $70: 805-816,1966$.

23) Cvek, M.G.L. and Hollender, $\vec{L}$. : Treatment of non-vital permanent incisors with calcium hydroxide. III. Variation of occurrence ankylosis of reimplantation of teeth with duration of extra-alveolen period and storage environment. Odont. Revy. 25:43-56, 1974.

24) Lenstrup, K. and Sküler, V. : A follow-up study of teeth replanted after accidental loss. Acta Odont. Scand. $17: 503-509,1959$.

25) Andreasen, J.O. : Periodontal healing after replantation of traumatically avulsed human teeth. Acta Odont. Scand. 33:325-335, 1975 .

26）石川梧朗・秋吉正豊：口腔病理学 I . 永末書店, 東京, $1978,359-360,361$.

27) 戸村二郎・青田 保：高周波電波による柬髄処置に関する実験的研究 (動物実験). 口病誌 24:24一39, 1957 .

28）石田利弘：完成宷再植後の治療過程に関する実験的研究一特に血管像ならびにX線所見一。口科誌 21 ： $625-651,1972$. 


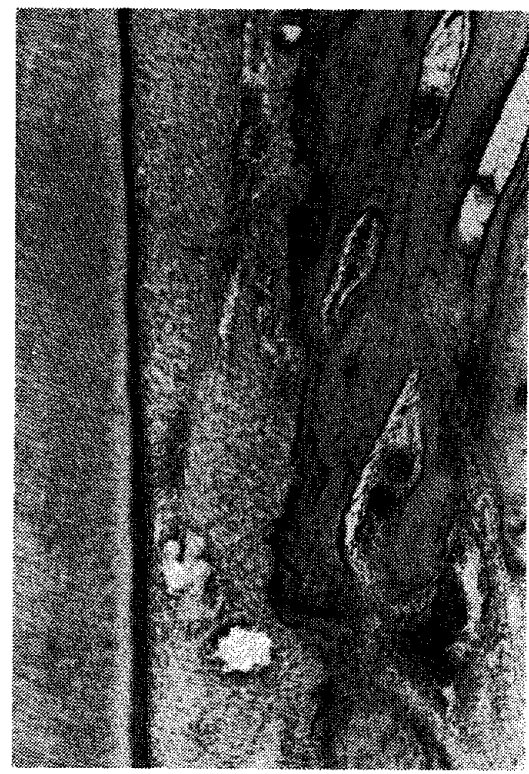

写真 111 対照群 $(\mathrm{HE}, \times 40)$

唇側霜根膜腔および周囲組織

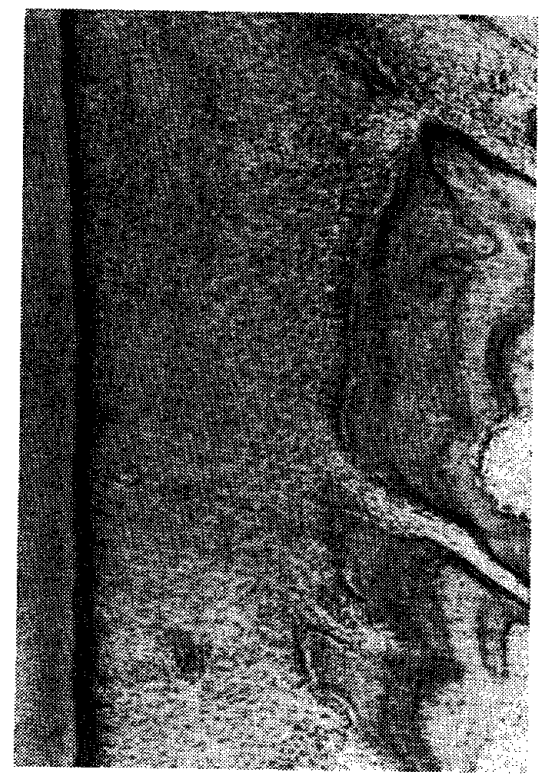

写真 $2 \quad \underline{1} \mid$ 対照群 $(\mathrm{HE}, \times 40)$

口蓋歯根膜腔周用組織および歯槽骨 (雪槽頂部)

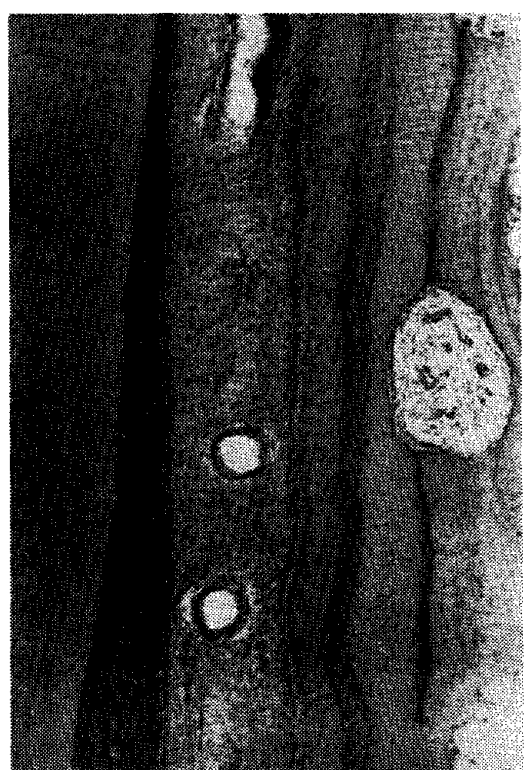

写真 $311 \mid$ 刘照群 $(\mathrm{HE}, \times 40)$ 上顎口蓋菌根膜腔および周囲組織 （根中央部）

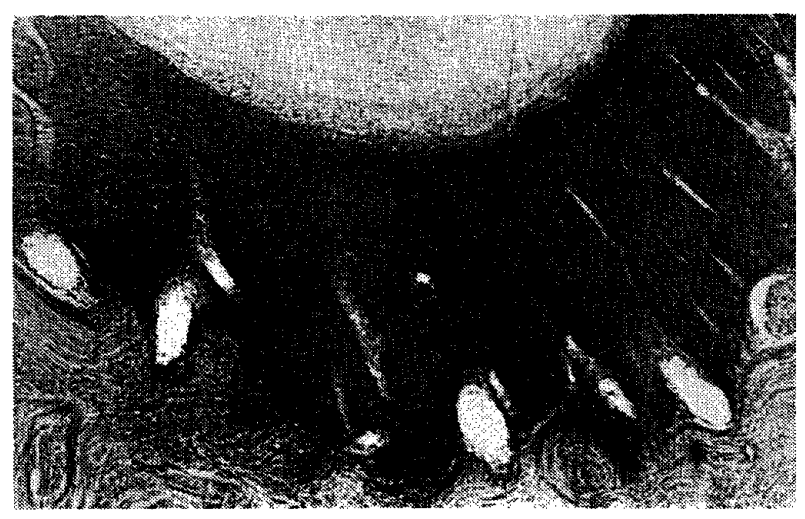

写真 4

1! 対照群（アザン・マロリー,×40） (根尖部) 


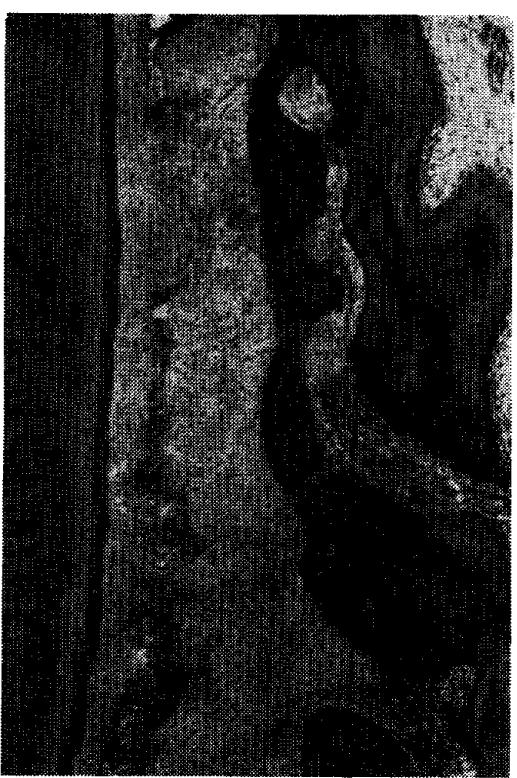

写真 5

1 再植後 3 日 ( H E, X 40)

唇側蒾根膜腔および周囲組織 （根中央部から根尖側 $1 / 3$ ）

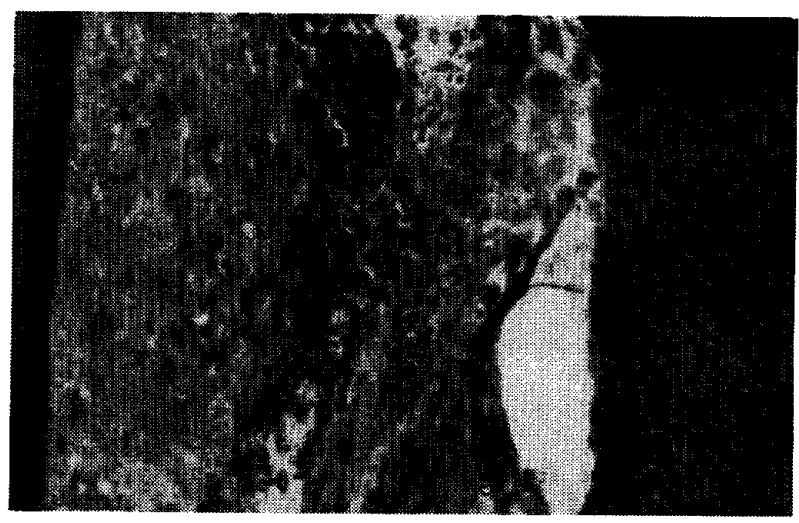

写真 7

1) 再植後 3 日

(アザン・マロリー, × 200)

唇側蒾根膜腔および周囲組織 (根中央部)

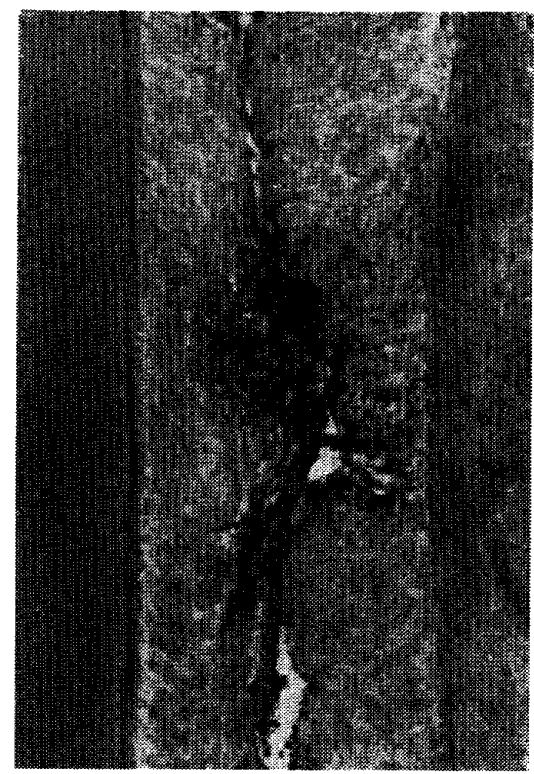

写真 6

唇側菌根膜腔および周囲組織 (根中央部)

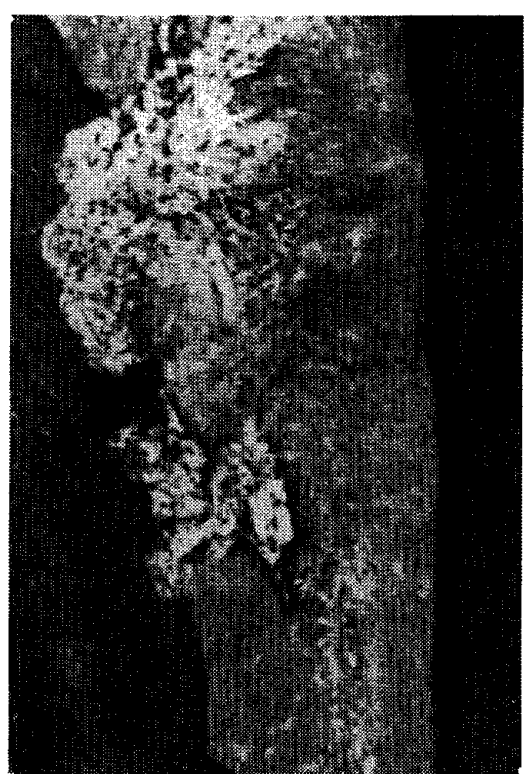

写真 $8 \underline{2}$ 再植後 5 日 $(\mathrm{HE}, \times 100)$ 唇側菌根膜腔おくび周囲組織 


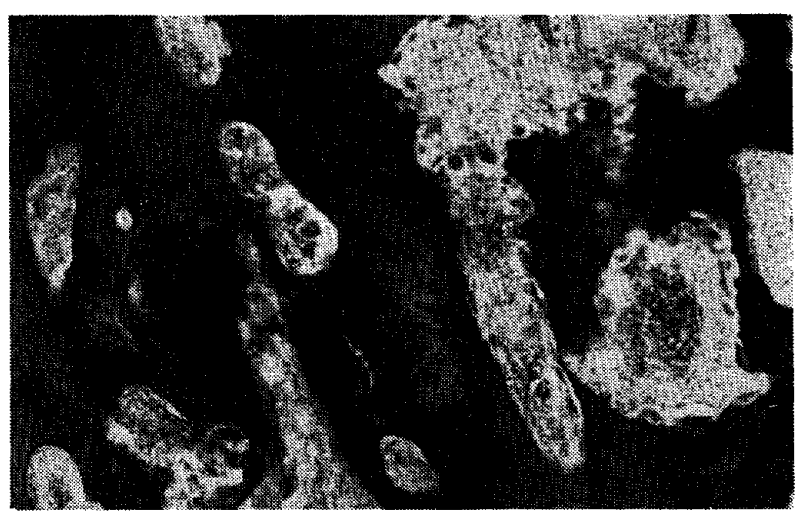

写真 $9 \leq 2$ 再植後 5 日 $(\mathrm{H} \mathrm{E}, \times 100)$ 口盖側歯槽骨”骨䯣腔

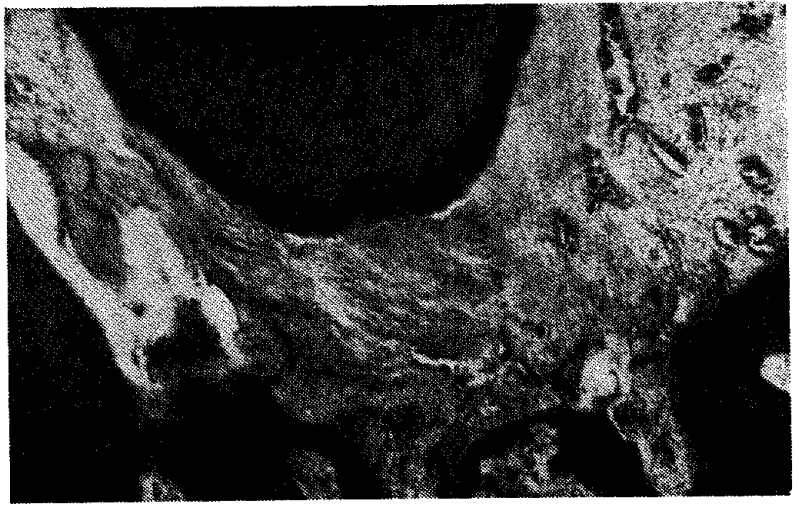

写真10 $\mid 2$ 再植後 5 日 $(\mathrm{HE}, \times 40)$ 根尖部雬根膜腔および周用組織

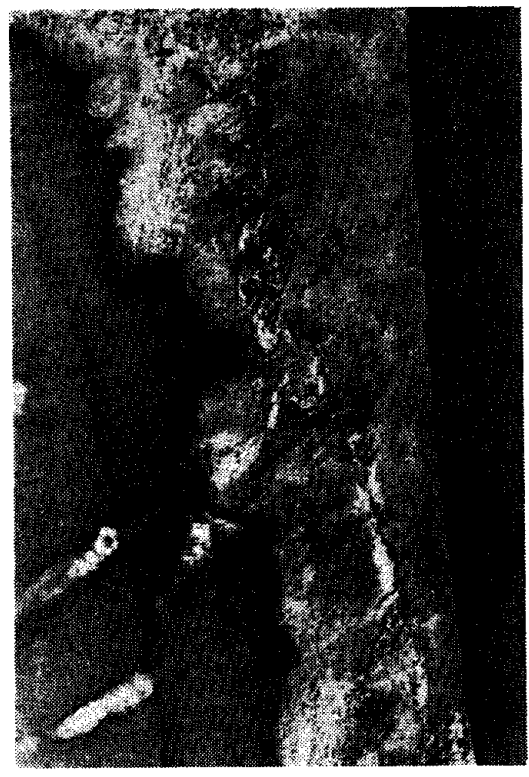

写真11 2 再植後10日 (H E , × 40) 口蓋雪根膜腔および周囲組織

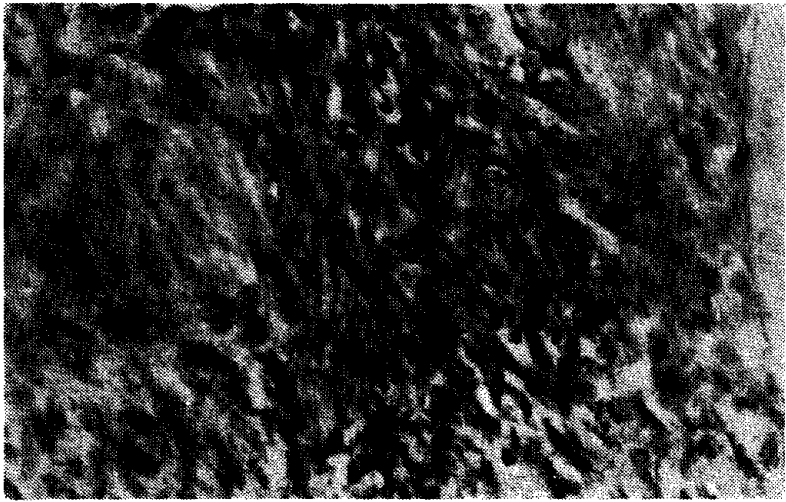

写真12 1 再植後10日

$$
\text { (アザン・マロリー, × 200) }
$$

唇側歯根膜腔断裂部

(根中央部) 


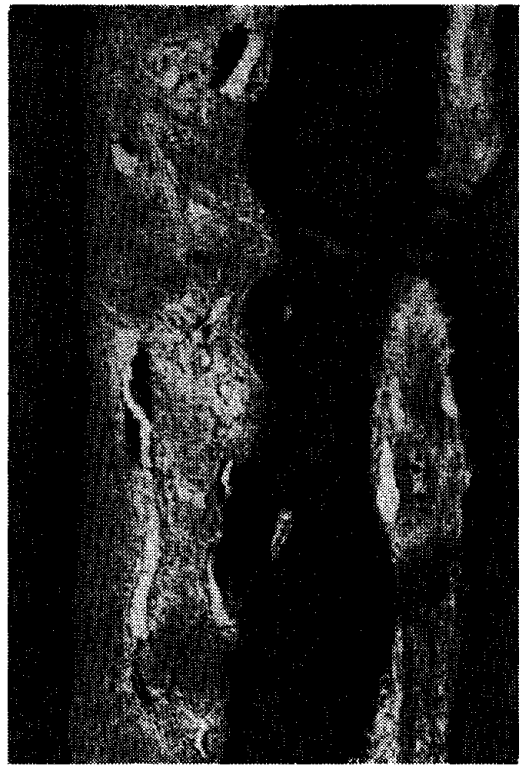

写真13

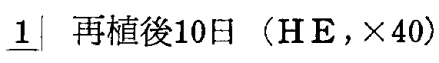

唇側菌根膜腔および周国組織

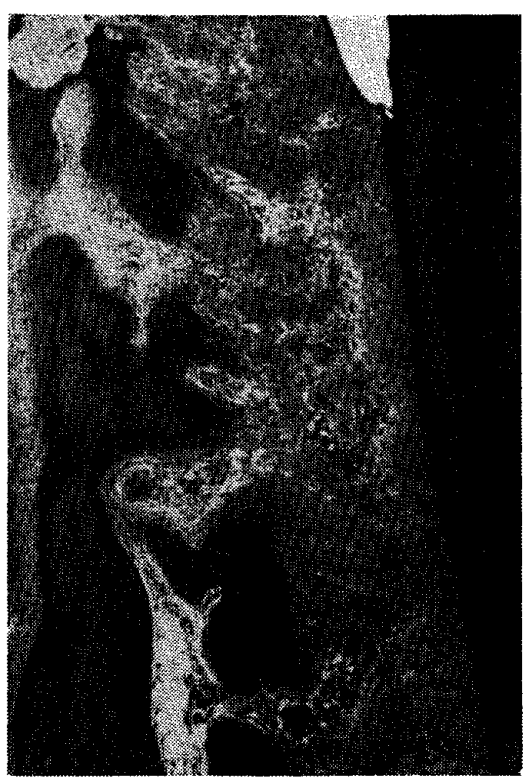

写真14

1) 再植後15日 $(\mathrm{HE}, \times 40\rangle$ 唇側画根膜腔および周囲組織 （歯頸部から根中央部）

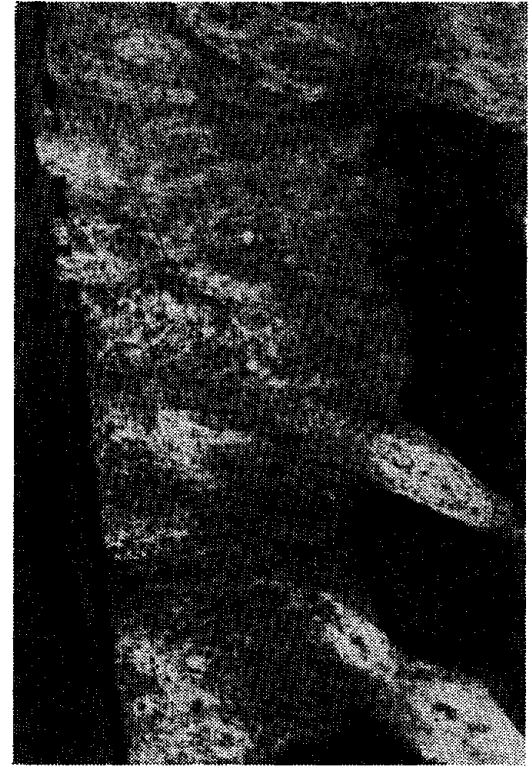

写真15 $1 \mid$ 再植後15日 $(\mathrm{HE}, \times 40)$ 口蓋側歯根膜腔および周囲組織 (雨槽頂部)

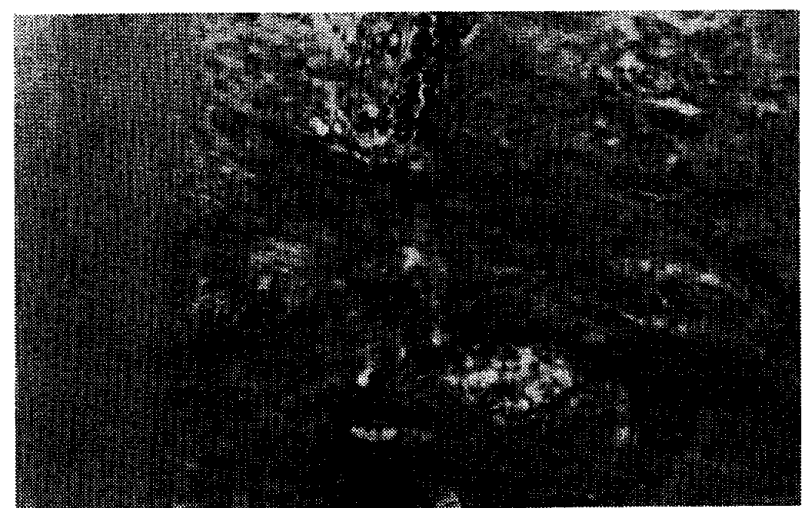

写真16 1 | 再植後15日 (アザン・マロリー, × 200) 口蓋雪根膜腔断裂部 (根中央部) 


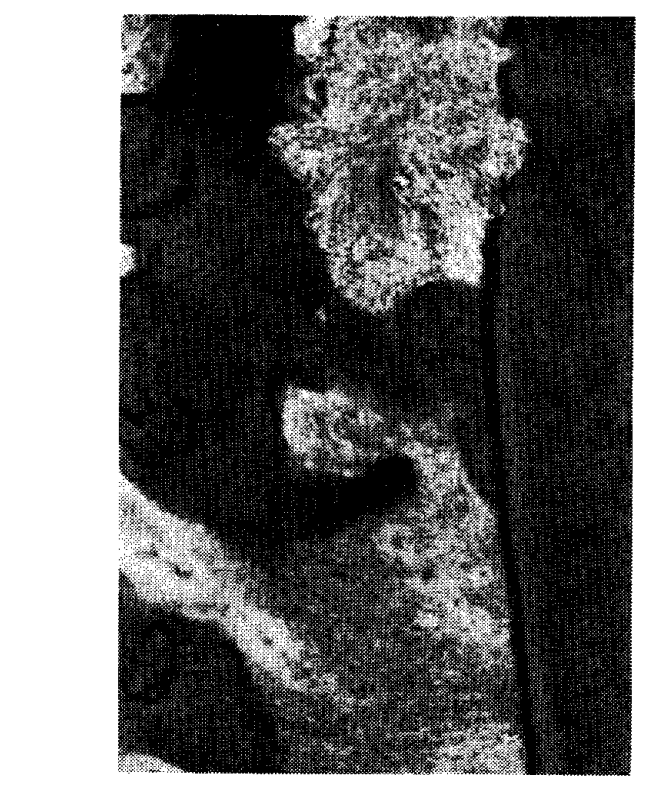

写真17

1. 再植後15日 $(\mathrm{HE}, \times 40)$

唇側菌根膜腔および周田組織 (根尖側 $1 / 3$ )

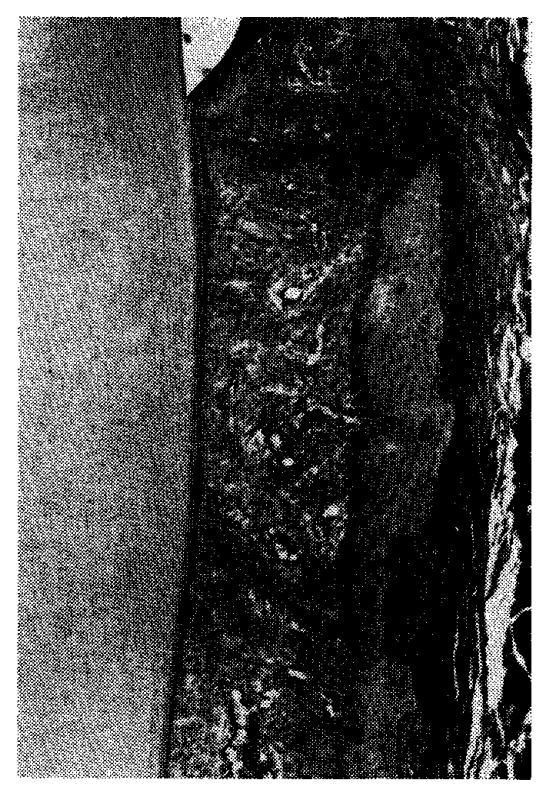

写真18 1 再植後20日

$$
\text { (アザン・マロリー, × 40) }
$$

唇側㐘根膜腔おうよ゙周囲組織

(歯頍部〜根中.央部)

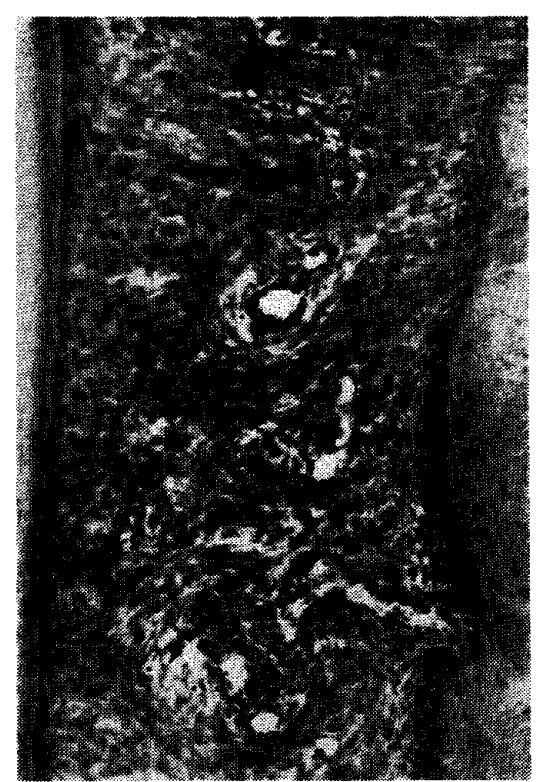

写真19 1 ! 再植後20日

$$
\text { (アザン・マロリー, ×100) }
$$

唇側蔽根膜腔

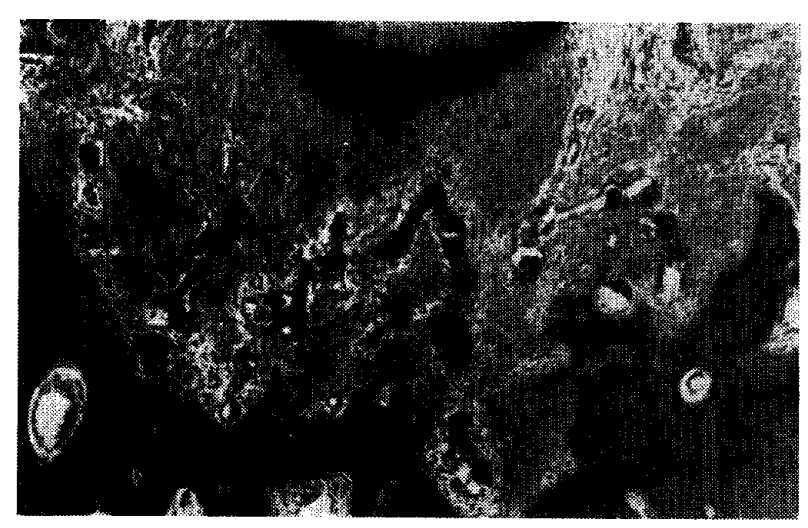

写真20 1 再植後20日( $\mathrm{HE}, \times 40)$ 根尖部棵根膜腔および凬团組織 


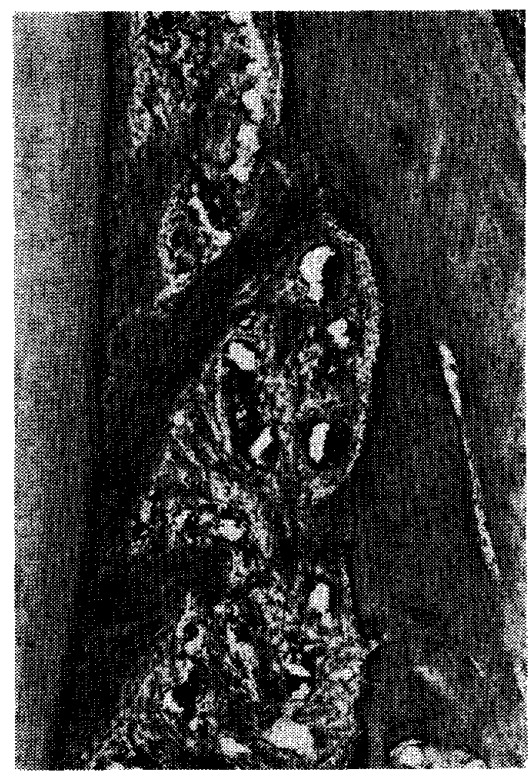

軍真21

1|再植後20日

$$
\text { (アザン・マロリー,×40) }
$$

唇僛菌根膜腔および閏囲組織

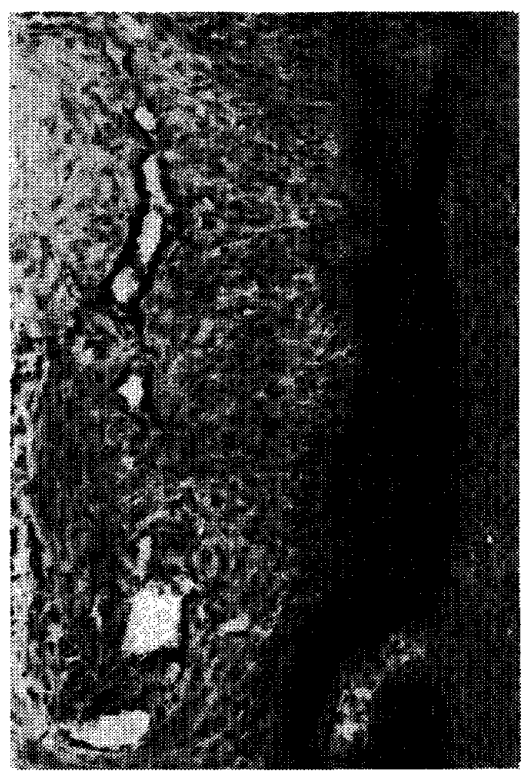

写真22 譬側歯根膜腔抢よび風囲組織

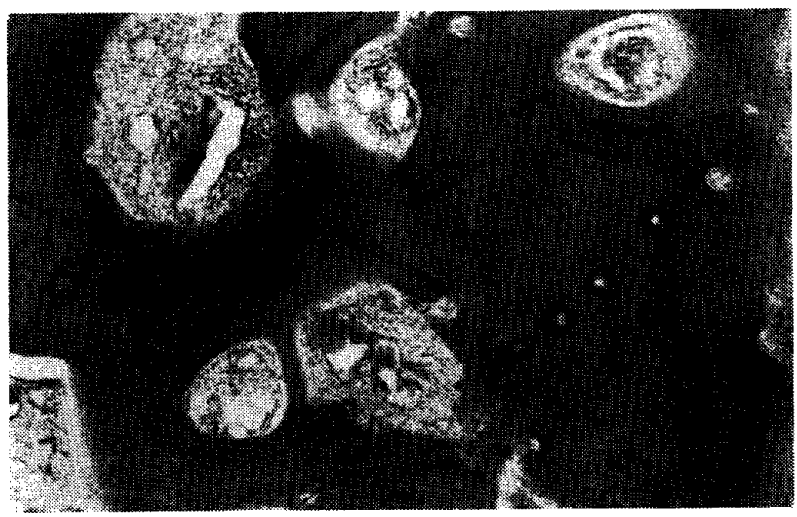

写真23 1：再植後20日 $(\mathrm{HE}, \times 100\rangle$ 口蓋歯槽,赍,骨笼腔

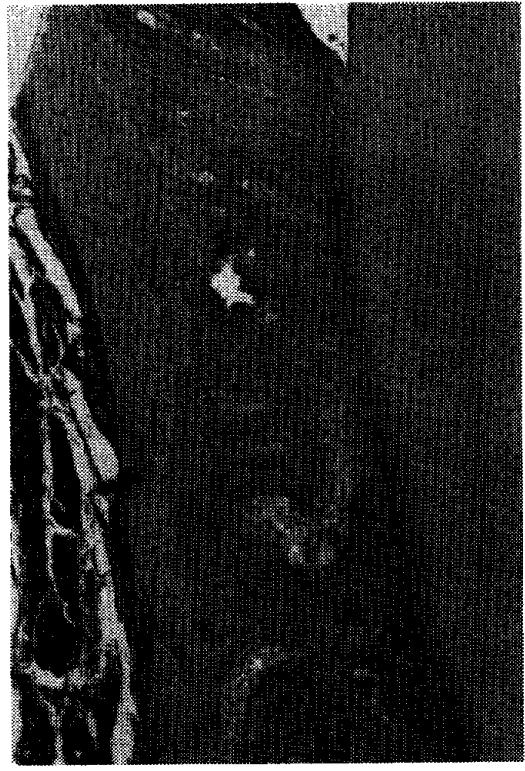

写真24 1 再植後30日

$$
\text { (アザン・マロリー, × } 40 \text { ) }
$$

辰側雪根膜腔および周井組織 （歯頸部汃ら根中央部） 


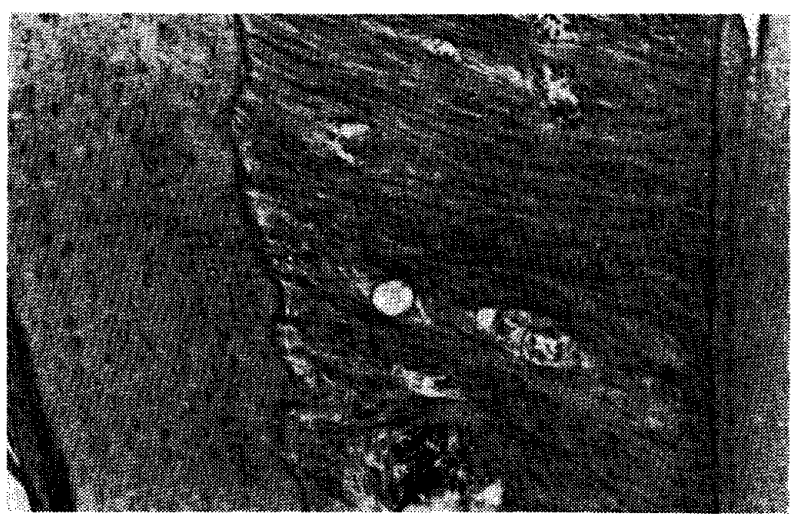

军真25 1 再植後30日

$$
\text { (アザン・マロリー, } \times 100)
$$

唇側荬根膜腟:

(歯頸部)

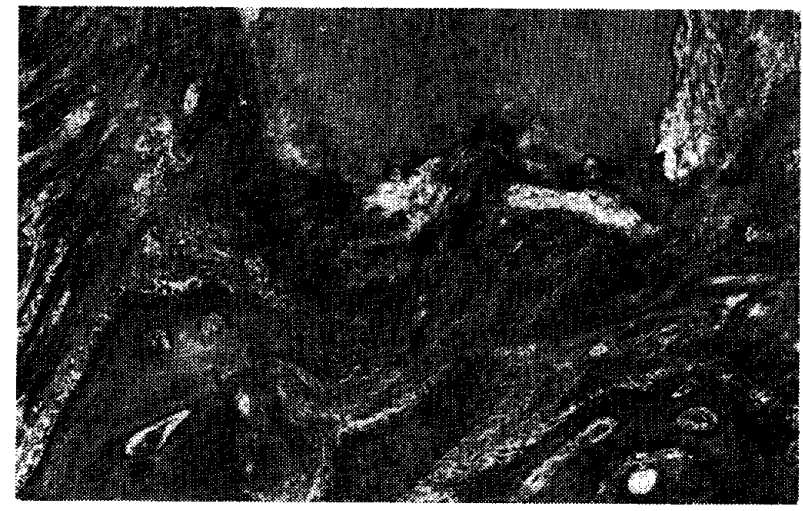

写真 $27 \lcm{2}$ 再植後45日

$$
\text { (アザン・マロリー, × } 40)
$$

根尖部柬根膜腔および周囲組織

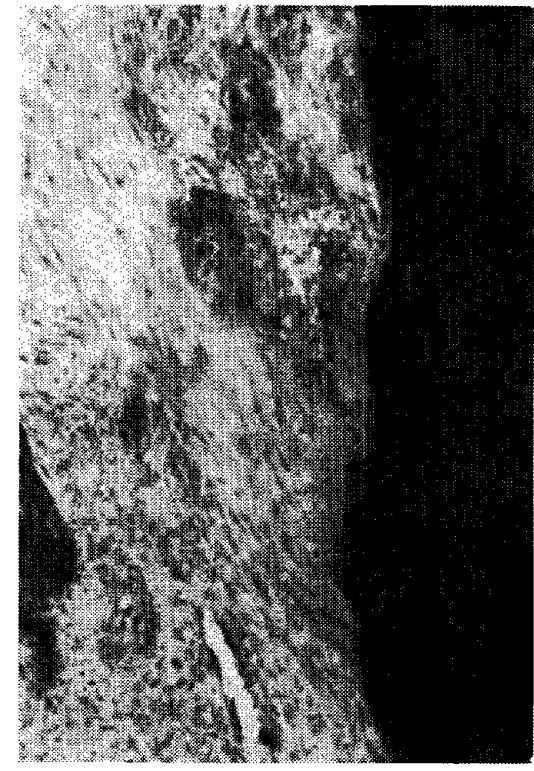

宁真26
1| 再楛後 30 日
唇側䨑根膜腔

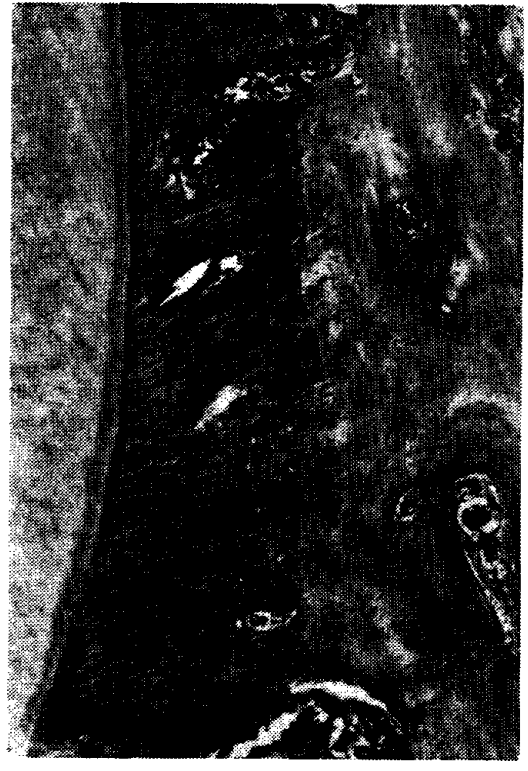

写真28

1! 平相後75日

$$
\text { アザン・マロリー，×40) }
$$

唇側菌根膜腔および周用組織 (根中央部汃ら根尖側 $1 / 3$ ) 


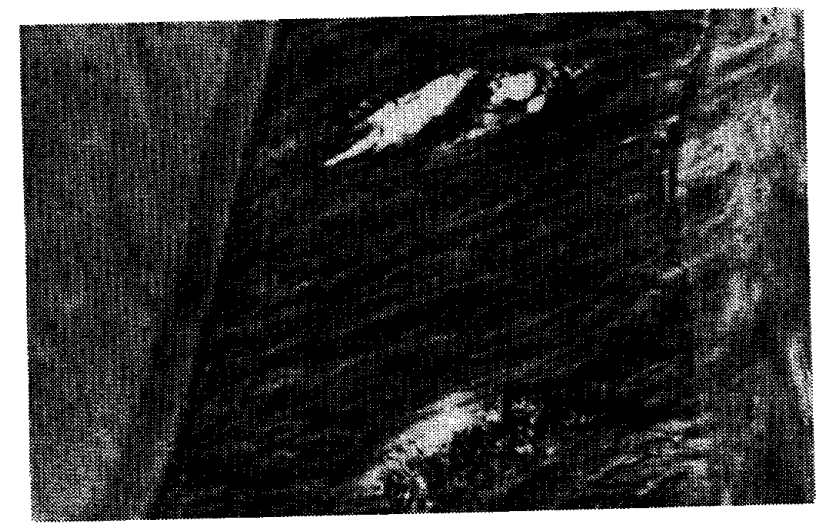

写真29 1 再植後75日

$$
\text { (アザン・マロリー, × 200) }
$$

唇側歯根膜腔

(根中央部) 强抎大

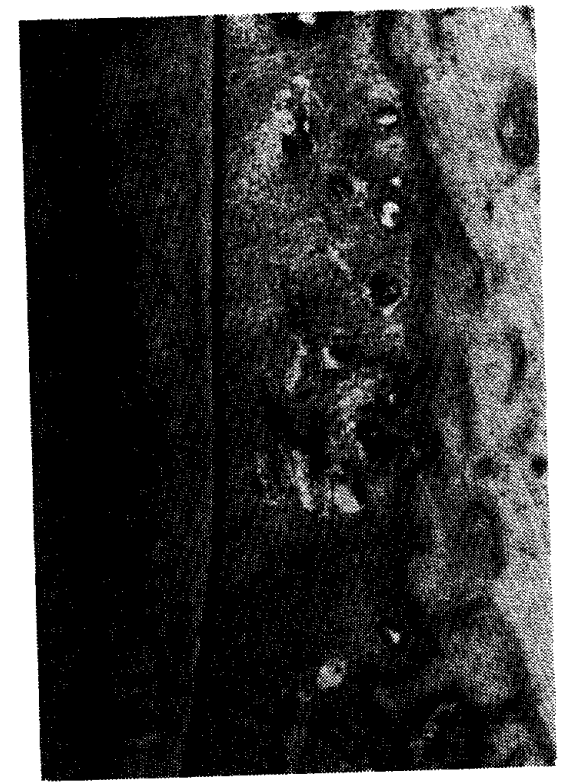

写真31 1 再植後90日 $(\mathrm{HE}, \times 40)$ 唇側歯根膜腔および周囲組織 （根中央部汃ら根尖側 $1 / 3$ )

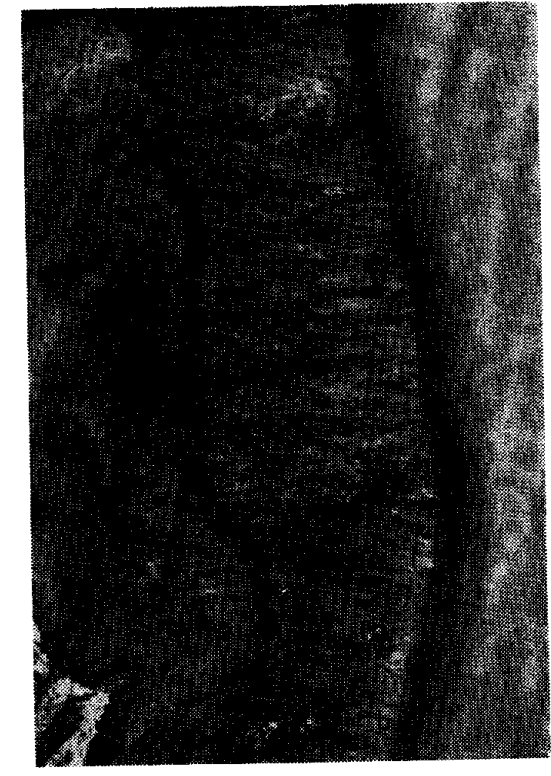

写真30
1. 再植後75日

$$
\text { (アザン・マロリー, ×100) }
$$

口蓋側歯根膜腔および周囲組織

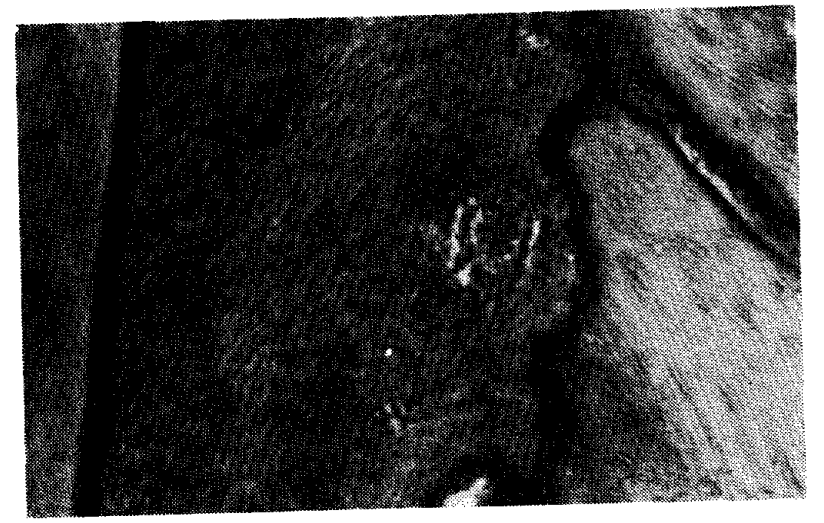

写真32 $\overrightarrow{\mathrm{I}} \mid$ 再植後90日 $(\mathrm{HE}, \times 200)$ 舌側歯根膜腔 

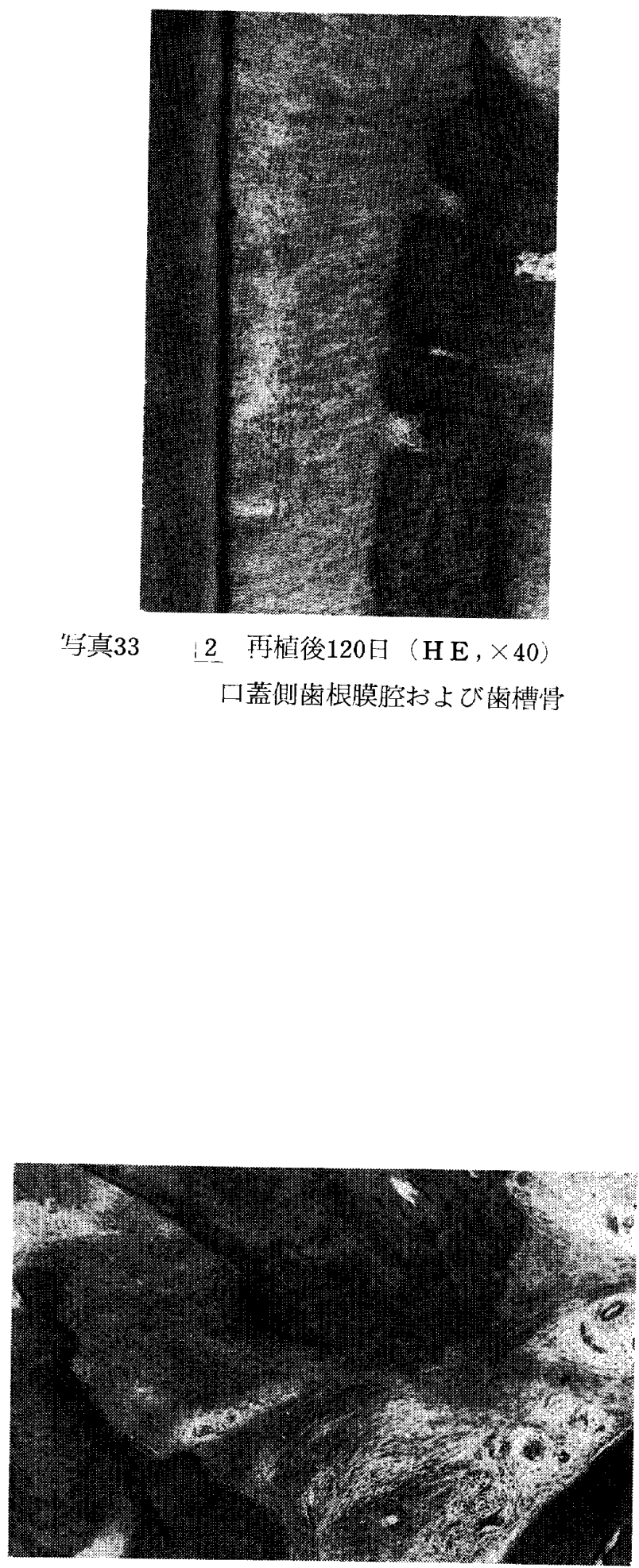

乌真34再植後120日 $(\mathrm{HE}, \times 100)$

12 根尖部

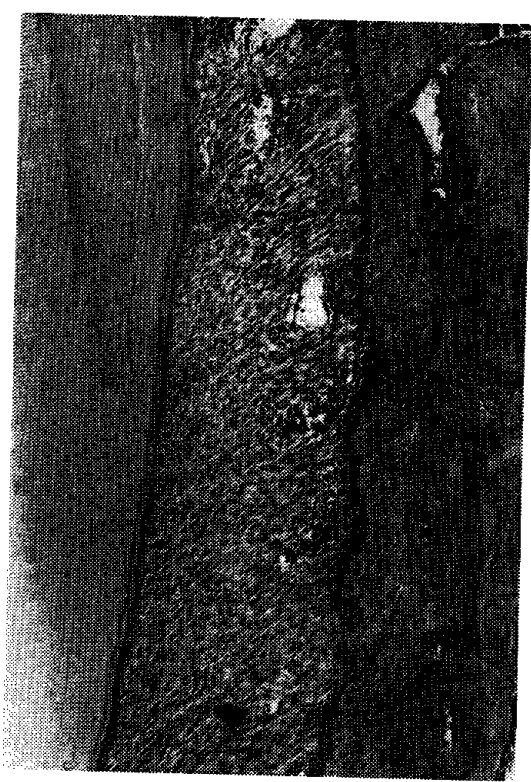

写真35

再植後120日

(アザン・マロリー, ×40)

2 唇側菡根膜腔および蒾槽骨

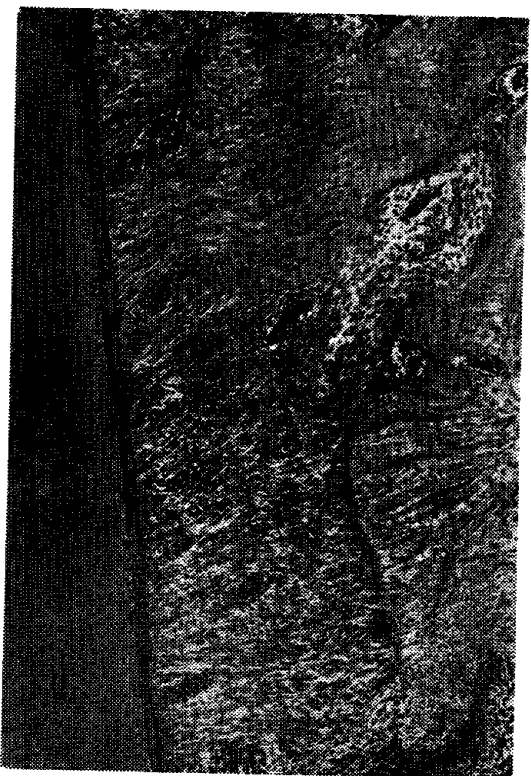

写真36 再植後120日

(アザン・マロリー,×40)

12 口蓋歯槽頂部 